\title{
Analysis of internal helically finned tubes for parabolic trough design by CFD tools
}

\author{
Javier Muñoz*, Alberto Abánades \\ Universidad Politécnica de Madrid, J.Gutiérrez Abascal, 2, 28006 Madrid, Spain
}

\begin{abstract}
A B S T R A C T
This paper has analysed the effect of the utilization of internal finned tubes for the design of parabolic trough collectors with computational fluid dynamics tools. Our numerical approach has been qualified with the computational estimation of reported experimental data regarding phenomena involved in finned tube applications and solar irradiation of parabolic trough collector. The application of finned tubes to the design of parabolic trough collectors must take into account features as the pressure losses, thermal losses and thermo-mechanical stress and thermal fatigue. Our analysis shows an improvement potential in parabolic trough solar plants efficiency by the application of internal finned tubes.
\end{abstract}

\section{Introduction}

Energy is one of the most important issues for our society development that is claiming for its sustainability through a reduction in the amount of its environmental effects by, for instance, limiting greenhouse gases emissions under international treaties [1], keeping at the same time the world energy generation and delivery capacity to fulfill the demand resulting from our socio-economical activity at reasonable costs to avoid the risk of a generalized economical recession. Such sustainability demands, at the current state-of-the-art of available energy generation and utilization technologies, a reduction of the fossil fuel dependence and an increase of renewables share on the global energy consumption scheme to increase primary energy sources diversification. Among renewables, solar energy has a huge potential to contribute to a significant worldwide energy production, although a lot of R\&D and commercial development is needed to achieve this role of massive energy source at competitive prices.

Regarding thermal solar-based electricity generation, there is a large variety of solar power plant configurations, mainly depending on the solar light concentration techniques, absorbing collector arrangements, and working fluids, both in the collectors and in the thermodynamic cycle. The most classical structure is based on parabolic trough collectors using mineral oil as high-temperature coolant feeding a Rankine steam cycle in the balance of power. This cycle is activated in a central water boiler heated by the oil coming from the solar field [2].
The efficiency in the process to produce electricity by solar thermal technologies can be roughly expressed, neglecting parasitic losses for the sake of simplicity in our following rationale, by the product of the solar field and cycle efficiencies, where $\eta_{\text {field }}$ stands for the field efficiency, what constitutes the ratio between the heat transferred to the heat transfer fluid and the beam solar radiation times aperture area of the solar field, and $\eta_{\text {cycle }}$ is the efficiency in the transformation of that heat into electricity through the thermodynamic cycle and the electric generator.

The field efficiency depends, for a given solar field configuration fixing parameters as mirror reflectivity, alignment, tracking ability and coating properties, mainly on the radiation thermal losses due to the temperature that the absorbing coating will reach. The absorber coating achievable temperature is technologically limited up to now [3] by the maximum thermal stress that can be assumed in the steel pipes and the radiation absorbing layer [4]. Obviously, a higher coating temperature will increase radiation thermal losses, reducing the field efficiency, but potentially increasing the outlet heat transfer fluid exergy. The cycle efficiency depends roughly on the exergy that can be transferred to the thermodynamic cycle, and, therefore, increases with the outlet temperature of the solar field heat transfer fluid. A loss of exergy is produced by the temperature difference between the absorber surface and the transfer fluid. The reduction of the thermal resistance between the inner tube side and the heated fluid imply a reduction of the exergy losses that are inferred by heat convection into the absorber tube and an increase in the outlet heat transfer fluid temperature that should remain always under the limits of the heat transfer fluid thermal stability. It is clear that an enhancement of the convection heat transfer into the tube of parabolic trough collectors, for a limited temperature coating, will increase the overall efficiency 
of this kind of solar plants, as the exergy gain in the heat transfer fluid increases.

Another relevant issue that must be addressed concerning trough absorbing tube design and operation is the minimization

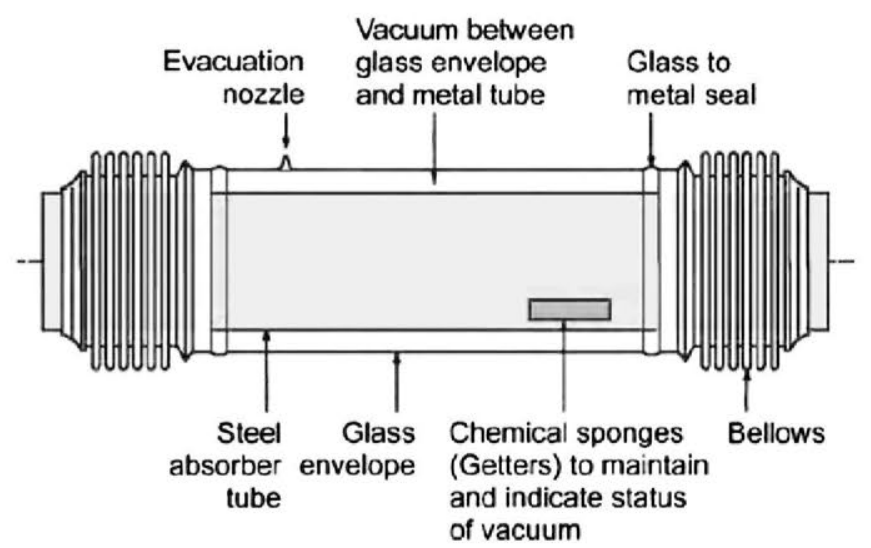

Fig. 1. Absorber pipe scheme [7].

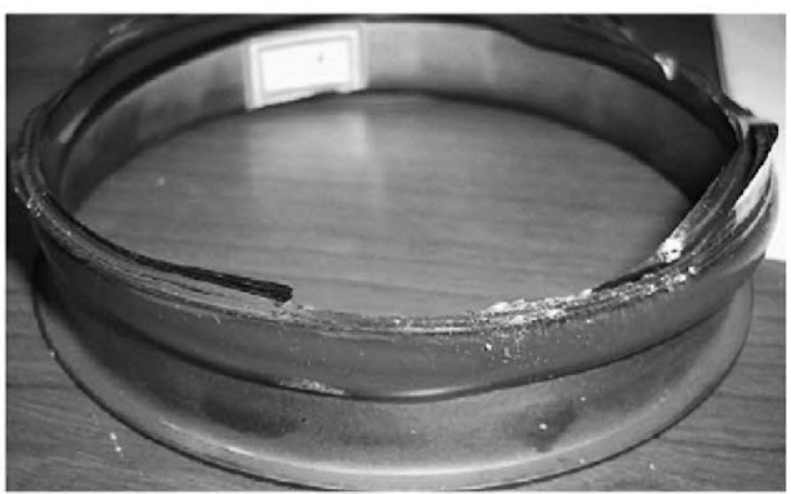

Fig. 2. Location of the fracture [6]. of the annular vacuum losses with time by the hydrogen permeation through absorber pipes due to thermal oil temperature degradation [5], what limits the lifetime of these devices. This thermal degradation occurs at low rate with temperatures below $400^{\circ} \mathrm{C}$, but accelerates considerably between $400^{\circ} \mathrm{C}$ and $425^{\circ} \mathrm{C}$.

Since the point of view of the glass-metal seal that must keep the vacuum between the glass envelope and the absorbing surface, the differential thermal elongation between both materials (Fig. 1) induced by the temperature difference between the glass and the absorbing tube, determined by radiation exchange between both surfaces, and their expansion coefficient, could also affect to the life of this component. Such sealing structure depends on the thermal expansion coefficient, material conductivity and Young's modulus (a material property related to its stiffness, defined as the ration between the stress and the material strain in the elastic range), and the sealing structure [6], producing a bending moment and shearing forces that depend on temperature gradients in the absorbing tube in normal operation and under transients. The effects of such mechanical stress has been reported and shown in Fig. 2 in an extreme way, but in minor effect could produce air filtrations.

The heating profile in the absorber tube resulting from the concentrating parabolic mirror optics has been analysed and measured $[7,8]$ having a shape as shown in Fig. 3, whose integration along the tube should provide the heat flux irradiating the absorbing tube. The effect of the solar heating is vanishing with high conductivity tubes [4], but its effects must be analysed when a low massflow transient takes place, with the risk of contact between the glass envelope and the absorbing tube because of the bending of the tube by the increase in the temperature difference in the tube due to a reduced convection heat transfer, producing a hot point by contact in the glass cover and its breakage.

The homogenization of the temperature field in the absorbing tubes is one of the relevant solutions that can be proposed to avoid breaking risks, hydrogen formation (avoiding excessive peak temperatures) and air filtration in the absorber tube. A mean to reduce temperature gradients in the metallic tube is the enhancement of the convection heat transfer mechanisms that evacuate the

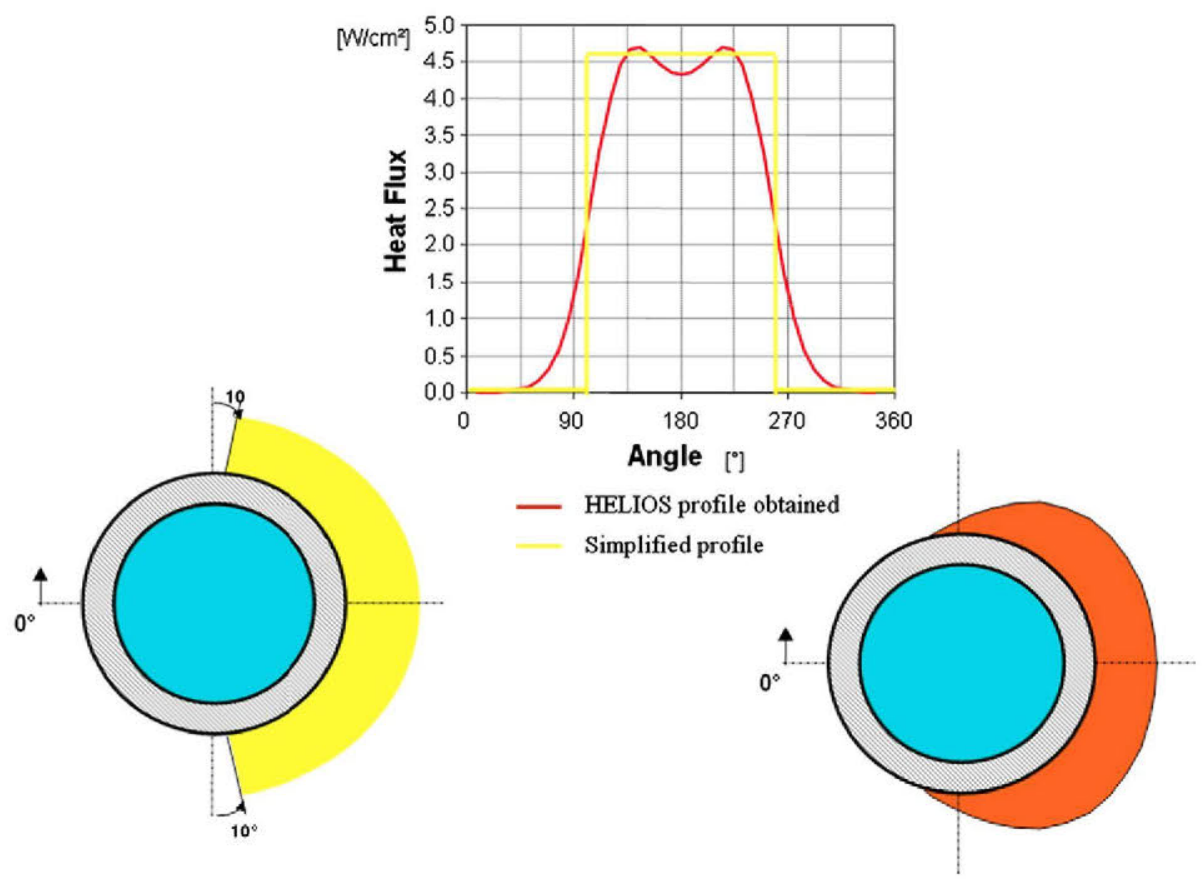

Fig. 3. Usual thermal power flux for an ET-Il collector obtained with the HELOS code and the simplified profile proposed for its simulation at nominal conditions $\left(\mathrm{DNl}=900 \mathrm{~W} / \mathrm{m}^{2}\right)[7]$. 
absorbed thermal energy to the heat transfer fluid. In this paper, the addition of internal fins in the collector absorbing pipes is analysed in order to assess the technological viability of such design chance in state-of-the art absorbing tubes. In particular, we will pay attention to its thermal-hydraulic behaviour, what affects the thermal efficiency of the collector and the parasitic losses that are induced by pumping power due to the expected increase in pressure losses for the application of internal finned tubes as substrate for the absorbing coating. To the author's knowledge, the application of helically finned tubes has not been study previously for parabolic trough collectors.

The plant efficiency, including the parasitic losses, can be expressed with the following relation:

$\eta_{t-e}=\eta_{\text {field }} \cdot \eta_{\text {cycle }}-\frac{W_{\mathrm{P}}}{A_{\mathrm{F}} \cdot \mathrm{DNI}}$

where the efficiency penalty due to the parasitic losses are formulated in function of the parasitic consumption $\left(W_{P}\right.$, that includes pumping power, tracking system consumption, etc.) and the direct normal irradiance (DNI) times the field surface $\left(A_{\mathrm{F}}\right)$. The utilisation of internal finned tubes will produce an increase on the required heat transfer fluid pumping that must be taken into account for a complete cost-benefit analysis of this design proposal.

This paper presents CFD study using the commercial code FLUENT [9] that has been applied for solar trough collectors by Ravi Kumar (2009) [10]. Internally finned tubes have not been studied since the author's knowledge for solar trough collectors, but the advantages of this design for enhance heat transfer has been documented in a great amount of papers [11-15]. Concretely de work done by Zdaniuk (2008) [15] has been taken to qualify the hydraulic side of the model. Moreover, with the work carried out by Forristal [16], based on the commercial code EES [17] and validated with the experimental data of Dudley [18] for the AZTRAK facility [19], the thermal side of the problem has been qualified. In general, FLUENT has been demonstrated its capacity to simulate with high accuracy complicated thermo-hydraulic problems with a huge amount of fluids and geometries $[10,20-26]$. The following sections explain briefly the main characteristics of the chosen CFD code, FLUENT, the methodology used, the model built to obtain the results and the conclusions of the work.

\section{Methodology}

The analysis of this design proposal has been done by numerical estimation of the absorbing tube performance from the thermalhydraulic point of view, evaluating its thermal behaviour and the pressure losses. A commercial multipurpose computational fluid dynamics (CFD) code FLUENT 6.3 [9] has been used as main tool in our analysis. Such code is used in many industries and fields for local thermal hydraulic analysis, including concentrated solar collectors [10], providing estimation of thermal systems that can be used for design improvements acting as a virtual laboratory or test-bench.

Every computational tool must be qualified for its purpose of application as a compulsory step to have confidence on its results and estimations. For such reason, we have qualified our numerical model with existing experimental data extracted from the available literature, either in relation with hydraulic or thermal phenomena.

There are a huge number of experimental studies related to flow through internal finned pipes as they can be applied in cooling technology [11-15]. Among them, we have selected the work carried out by Zdaniuk [15]. That work shows recent pressure drop data for a wide set of different pipe geometries and hydraulic re- gimes with water, what constitutes a worthy test to evaluate the accuracy of our model in relation to hydraulic analysis of internal finned tubes. This comparison has given us confidence in our pressure drop estimation. The results of the qualification with those experimental data will be shown in next sections.

The estimation of the thermal behaviour with our model has been qualified with its application to the analysis of the experimental data obtained in the AZTRAK facility [19] and its comparison with the EES [17] model developed by Forristal [16]. This work shows experimental and calculated data for a parabolic trough absorbing tube under real irradiation, what implies a heterogeneous heat deposition on the tube with Syltherm 800 as heat transfer fluid. The application of a 3-D model for such analysis is required as the un-homogeneous energy deposition in the absorbing tube has an strong influence in the temperature obtained in the collector tube that are of paramount importance for the evaluation of the thermo-mechanical stress that produce tube bending and deformation, and material fatigue. We have evaluated the effect of the un-homogeneity of the thermal flux and we have found that temperature difference due to that fact is around $90{ }^{\circ} \mathrm{C}$ for the same energy absorption in the collector. Such estimation will be shown in the section concerning the thermal model.

Once the qualification of the code is done, we proceed to compare a design proposal of internal finned absorbing tubes with current commercially available tubes for parabolic troughs, concluding with the assessment of the advantages and disadvantages of the application of the proposed design.

\section{The numerical model}

Both experimental data sets have been reproduced with the same computational methodology. As it has been mentioned, we have developed a CFD model for long tube simulation. Computational fluid dynamics analysis is a very worthy engineering tool for local phenomena characterization of mass and momentum conservation laws in a given domain by finite-difference approximation. Nevertheless such codes have the limitation of the large amount of computational resources that are required for an accurate solution in large volumes due to the large amount of cells and nodes that should be used in a reliable model. Parabolic trough collectors have lengths of the order of tens of meters with diameter of centimetres, what makes unlikely a fullgeometry CFD analysis. That approach is also unlikely for finned long tubes.

In order to handle a reliable and affordable model, we have applied a simulation procedure based on the sequential execution of tube partitions in which the initial boundary conditions in the form of massflow inlet are obtained from the massflow outlet obtained in the previous tube section. The coupling between tube partitions requires the compatibility between their meshes, what is fully fulfilled with the same mesh structure in the inlet and the outlet

Table 1

Experimental data for LS-2 collector in the AZTRAK facility [18].

\begin{tabular}{llllllll}
\hline & $\begin{array}{l}\text { DNI } \\
\left(\mathrm{W} / \mathrm{m}^{2}\right)\end{array}$ & $\begin{array}{l}\text { Air } T \\
\left({ }^{\circ} \mathrm{C}\right)\end{array}$ & $\begin{array}{l}\text { Flow rate } \\
(1 / \mathrm{min})\end{array}$ & $\begin{array}{l}T \text { in } \\
\left({ }^{\circ} \mathrm{C}\right)\end{array}$ & $\begin{array}{l}T \text { out } \\
\left({ }^{\circ} \mathrm{C}\right)\end{array}$ & $\begin{array}{l}\Delta T \\
\left({ }^{\circ} \mathrm{C}\right)\end{array}$ & $\begin{array}{l}\text { Error } \\
(\%)\end{array}$ \\
\hline LS-2 \#1 & 933.7 & 21.2 & 47.7 & 102.2 & 124 & 21.8 & 1.95 \\
LS-2 \#2 & 968.2 & 22.4 & 47.8 & 151 & 173.3 & 22.3 & 1.92 \\
LS-2 \#3 & 982.3 & 24.3 & 49.1 & 197.5 & 219.5 & 22 & 1.81 \\
LS-2 \#4 & 909.5 & 26.2 & 54.7 & 250.7 & 269.4 & 18.7 & 1.90 \\
LS-2 \#5 & 937.9 & 28.8 & 55.5 & 297.8 & 316.9 & 19.1 & 1.86 \\
LS-2 \#6 & 920.9 & 29.5 & 56.8 & 379.5 & 398 & 18.5 & 2.41 \\
LS-2 \#7 & 903.2 & 31.1 & 56.3 & 355.9 & 374 & 18.1 & 2.36 \\
\hline
\end{tabular}


Table 2

Tube geometries analysed by Zdaniuk [15].

\begin{tabular}{|c|c|c|c|c|c|c|c|c|}
\hline \multirow[t]{2}{*}{ Tube } & \multicolumn{3}{|l|}{ External structure } & \multirow{2}{*}{$\begin{array}{l}\text { Copper wall } \\
\text { thickness (mm) }\end{array}$} & \multicolumn{4}{|l|}{ Internal surface } \\
\hline & $\begin{array}{l}\text { Outside nominal } \\
\text { diameter (mm) }\end{array}$ & Fin pitch (fins/in.) & Fin height (mm) & & Fin height (mm) & $\begin{array}{l}\text { Number of } \\
\text { starts (-) }\end{array}$ & Helix angle (deg) & $\begin{array}{l}\text { Internal nominal } \\
\text { diameter (mm) }\end{array}$ \\
\hline \#1 & 18.82 & 40 & 0.945 & 0.645 & 0.38 & 10 & 25 & 15.64 \\
\hline \#2 & 18.82 & 40 & 0.925 & 0.68 & 0.375 & 30 & 25 & 15.61 \\
\hline \#3 & 18.86 & 40 & 0.94 & 0.68 & 0.38 & 30 & 48 & 15.62 \\
\hline \#4 & 18.79 & 40 & 0.925 & 0.685 & 0.38 & 45 & 25 & 15.57 \\
\hline$\# 5$ & 18.82 & 40 & 0.90 & 0.71 & 0.31 & 45 & 35 & 15.6 \\
\hline \#6 & 18.79 & 40 & 0.93 & 0.68 & 0.38 & 45 & 35 & 15.57 \\
\hline \#7 & 18.82 & 40 & 0.935 & 0.68 & 0.51 & 45 & 35 & 15.59 \\
\hline$\# 8$ & 18.77 & 40 & 0.925 & 0.67 & 0.38 & 45 & 48 & 15.58 \\
\hline$\# 9$ & 18.85 & 40 & 0.93 & 0.67 & 0 & - & - & 15.65 \\
\hline
\end{tabular}

boundary surfaces and the development of the required user defined function to assess boundary conditions at each simulation step. This fact has forced, for instance, to fix the partition length in the case of helically finned tubes to a multiple of the helix period.

In our 3-D model, the nodal network is composed by triangular prismatic cells in solid regions comprising pipe walls and quadrangular prismatic cells in the fluid domain. Boundary layer between the walls and the flow was defined to assess a $y^{+}$. This term measures the gradient of the fluid variables at every cell known as dimensionless wall distance, lower gradients means a better accuracy of the model. This dimensionless wall distance is given as:

$y^{+} \equiv \frac{u * y}{v}$

where $u^{*}$ is the friction velocity at the nearest wall, $y$ is the distance to the nearest wall and $v$ is the local kinematic viscosity of the fluid. The $y^{+}$is commonly used in boundary layer theory and in defining the law of the wall $[9,10]$. In the considered CFD model is wanted a value of $y^{+}$of the order of 1 to have confidence in the 'enhanced wall treatment' coupled to a RNG $k-\varepsilon^{1}$ turbulent model.

Such model yields proper predictions of near wall, separated and curved flows in tubular surfaces [20], giving a better approach to rapid strain and streamline curvatures, flow separation, reattachment and recirculation than the standard $k-\varepsilon$ model. The RNG $k-\varepsilon$ model is also reported to give accurate predictions for the velocity field, the turbulent kinetic energy and the recirculation length [14]. The convergence criteria in our analysis has been fixed in residual values less than $1 e-5$, even for the continuity equations, what is quite restrictive in comparison with similar reported works [20].

A complete evaluation of the thermal losses by convection to the air and radiation to the sky by CFD implies a huge amount of computational resources and time, with foreseen convergence problems due to the complexity of the required model. Therefore, the thermal losses by convection and radiation have been introduced as a boundary condition at the pipe surface in the form of an external function depending on the tube surface temperature, which has been obtained with the EES model developed by Forristal [16]. That function depends on the operational conditions that has been fixed in an external air temperature of $21.2^{\circ} \mathrm{C}$, a null wind speed, and a Syltherm 800 massflow of $0.68-0.71 \mathrm{~kg} / \mathrm{s}(47.18-$

\footnotetext{
1 The RNG model was developed using Re-Normalisation Group (RNG) methods by Yakhot and Orszag [21] to renormalise the Navier-Stokes equations, to account for the effects of smaller scales of motion. In the standard $k-\varepsilon$ model the Eddy viscosity is determined from a single turbulence length scale, so the calculated turbulent diffusion is that which occurs only at the specified scale, whereas in reality all scales of motion will contribute to the turbulent diffusion. The RNG approach, which is a mathematical technique that can be used to derive a turbulence model similar to the $k-\varepsilon$, results in a modified form of the epsilon equation which attempts to account for the different scales of motion through changes to the production term.
}

49.27 1/min), based on the experimental conditions of LS-2 \#1 data set shown in Table 1 (LS-2 refers to Luz System Collector type 2 [18], and \#1 to the number one of the data in the cited table). The thermal losses density we have introduced in our model are the following in function of the absorbing surface temperature $T$ (K):

$$
\begin{aligned}
& \text { Thermal losses density }\left[\mathrm{W} / \mathrm{m}^{2}\right] \\
& \quad=673.17+1.09 \cdot T+8.15 e-9 \cdot T^{4}
\end{aligned}
$$

The thermal losses density correlation as a function of the absorber outer surface temperature in Kelvin (Eq. (3)) can be obtained from the Forristall model [16] adapted to the considered collector for the environmental conditions of LS- 2 \#1 for the absorber temperature range $100-300^{\circ} \mathrm{C}$. Obviously, this assumption regarding the evaluation of the thermal losses of the pipe section will need an 'ad hoc' evaluation for every set of operational conditions for a fine analysis.

Regarding material properties, they were introduced in the code as a polynomial function, as was the case of the heat transfer fluid passing through the absorbing tubes of parabolic trough collectors.

\section{Numerical model qualification}

The model qualification has been done in two steps. First, we have compared our models with experimental data to assess its accuracy in the analysis of finned tube geometries. For such comparison we have selected the set of experiments done by Zdaniuk et al. [15]. Table 2 shows the complete set of experiments that
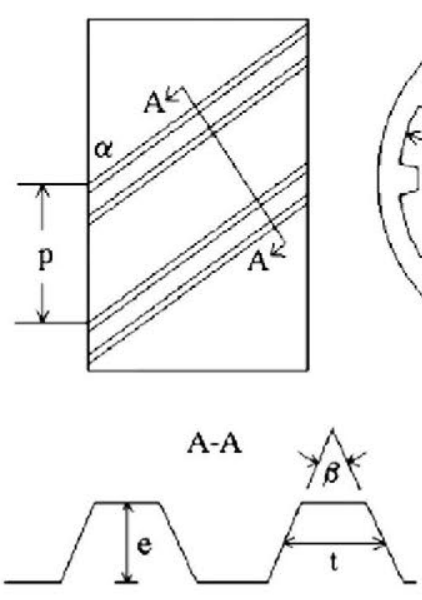

Fig. 4. Geometric variables of the helical fin [15].

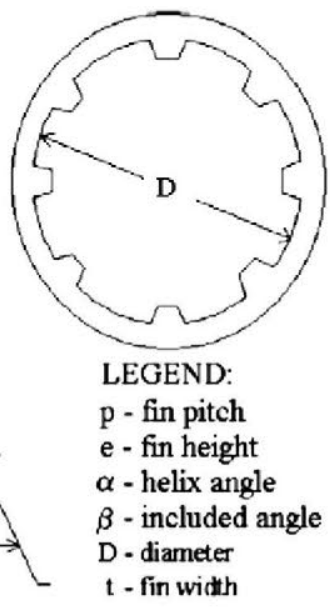


were performed, although for our purpose we only take into account the internal surface geometry. Fig. 4 shows the description of the parameters that characterised the pin geometry of each tube. Among the complete tube data set, we have reproduced for our qualification the data related to tube \#1 and \#9. Tube \#1 is an internal finned tube with a moderated helix angle and longitudinal fluid swirl, near to our expectation for our parabolic trough design proposal as pressure drop increase might be limited to avoid excess parasitic losses penalty. On the contrary, tube \#9 is a plain tube that can be considered as a reference starting point for comparison and model development. A summary of the main parame-

Table 3

Main parameters regarding models for Zdaniuk tubes.

\begin{tabular}{clllll}
\hline Case & $\begin{array}{l}\text { Number } \\
\text { of nodes }\end{array}$ & $\begin{array}{l}\text { Geometry } \\
\text { length } \\
(\mathrm{m})\end{array}$ & $\begin{array}{l}\text { Required } \\
\text { partitions }\end{array}$ & $\begin{array}{l}\text { Simulation } \\
\text { total } \\
\text { length }(\mathrm{m})\end{array}$ & Comments \\
\hline $\begin{array}{c}\text { Zdaniuk's \#9 } \\
\text { (smooth) }\end{array}$ & $\sim 775.000$ & 2743 & 1 & 2.743 & - \\
$\begin{array}{c}\text { Zdaniuk's \#1 } \\
\text { (finned) }\end{array}$ & $\sim 686.000$ & 0.1054 & 26 & 2.743 & $\begin{array}{l}\text { One helix } \\
\text { turn }\end{array}$ \\
\hline
\end{tabular}

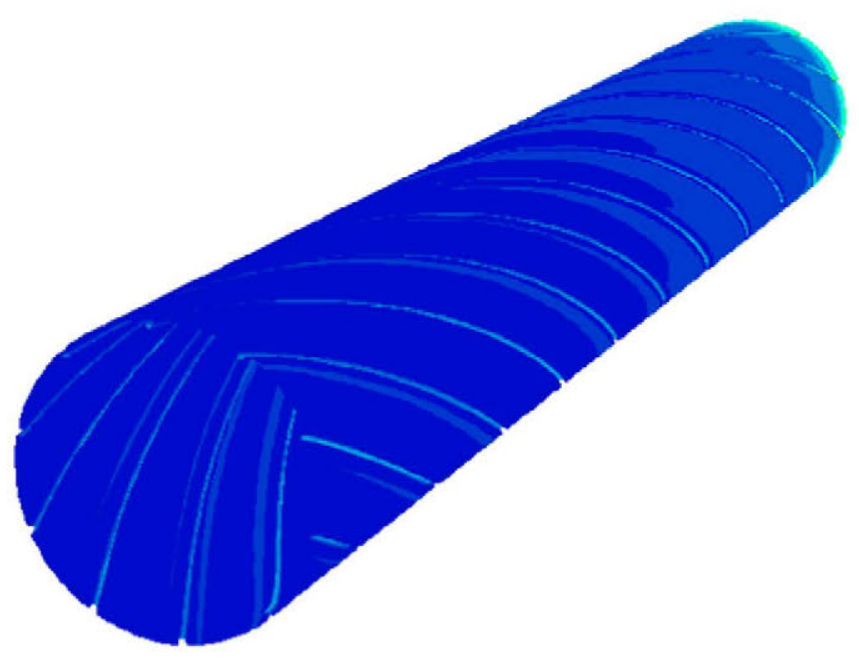

Fig. 5. Model for each partition of tube \#1 corresponding to the length of a helix turn. ters of our simulation is given in Table 3 . The plain tube has been simulated with a single partition and the finned tube was modelled with a 26 partition scheme, each partition corresponding to a helix turn and with a resolution of the order of 700,000 nodes. Fig. 5 shows our surface model for that finned tube \#1, where the fin geometry can be seen.

The results of our simulation have been compared with the experimental data by the analysis of the Fanning coefficient ( $f f$ ), a common dimensionless number related to the pressure losses and the shear stress at the tube wall, what is defined as:

$f f=\frac{\Delta P \cdot D}{2 \cdot L \cdot \rho \cdot v^{2}}$

where $\Delta P$ are the pressure losses, $D$ the tube diameter, $L$ the tube length, $v$ the fluid velocity and $\rho$ the fluid density. Fig. 6 shows the pressure drop qualification of our model with a very good agreement between the experimental data and our CFD estimation. Note that the Blasius correlation slightly underestimates the pressure losses in the plain smooth tube as it does not take into account the development of the boundary layer and turbulence at the inlet of the tube, what is fully considered in the experimental data and the 3-D CFD simulation. Such discrepancy becomes negligible as the tube length increases. This fact gives enough confidence in our methodology in relation with the pressure drop evaluation regarding finned tubes.

As it was mentioned in previous paragraphs, a qualification exercise was done for the thermal accuracy of our model with experimental data provided by Dudley et al. [18] and the simulation provided by Forristal [16] concerning the AZTRAK facility [19]. The experimental data has been obtained with real irradiation of the LS-2 collector pipe with a geometry configuration very close to any proposed stainless steel parabolic trough tube, with a $66 /$ $70 \mathrm{~mm}$ inner/outer diameter with $20 \mu \mathrm{m}$ roughness and a length of almost $8 \mathrm{~m}$ [18].

We have estimated such experiment with a 10 partition scheme. Each partition represents $0.7795 \mathrm{~m}$ (for the actual length of $7795 \mathrm{~m}$ of the experimental tube) modelled with a 443,000 cell nodal network. Forristal [16] simulated the experiment with an EES [17] model, a common tool for thermal analysis based on an equation solver. A comparison between the results given by the EES model and our CFD model is shown in Figs. 7-9 concerning temperature and pressure drop in a test LS-2 \#1 as referred in Table 1. Thermal estimation by both models is in a very good agreement, with a discrepancy lower than $0.1 \%$ in the complete

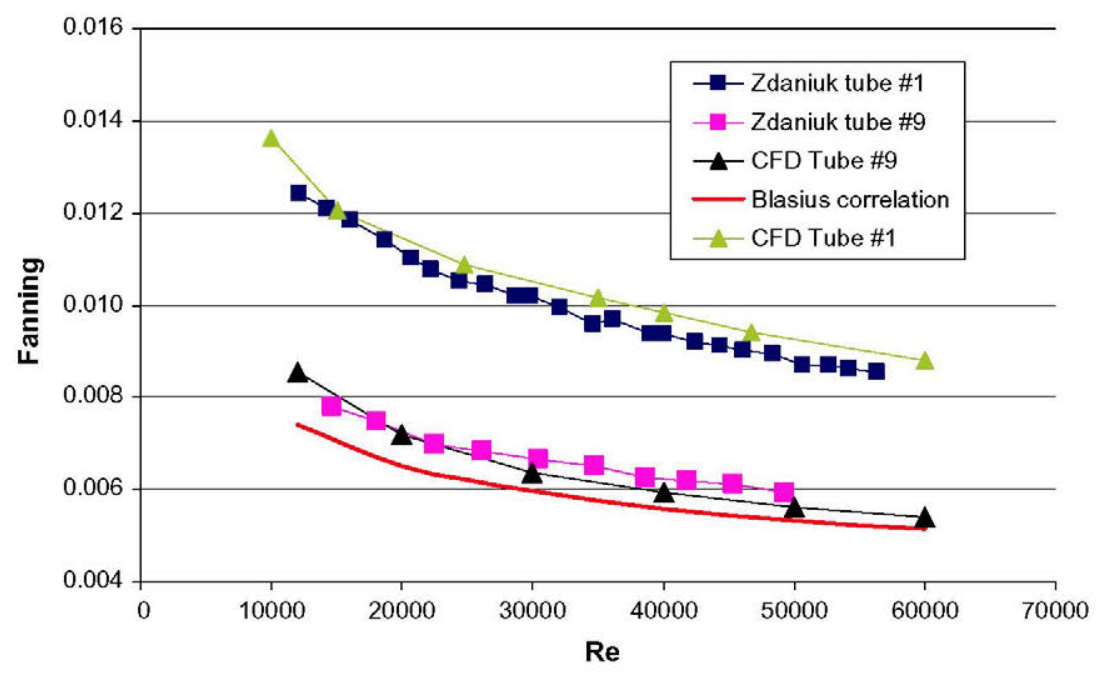

Fig. 6. Comparison between experimental data and CFD model for tubes \#1 (finned) and \#9 (plain). 


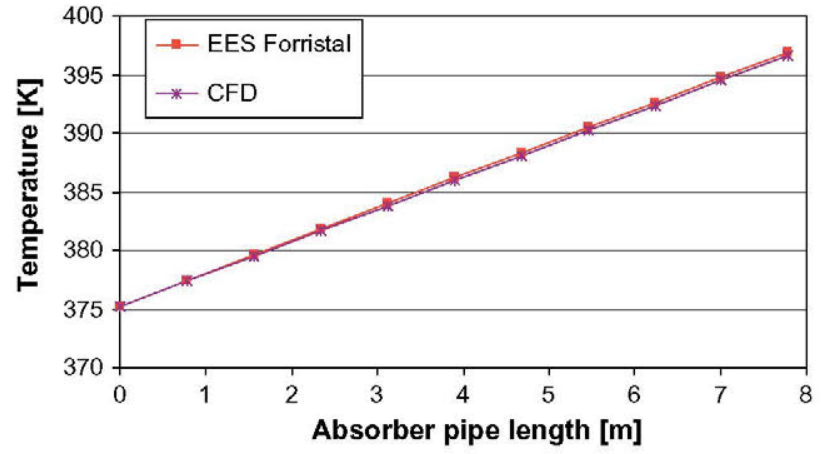

Fig. 7. Temperature comparison between CFD and EES model (massflow $=47.7 \mathrm{l}$ $\min , \mathrm{DNI}=933.7 \mathrm{~W} / \mathrm{m}^{2}$ )

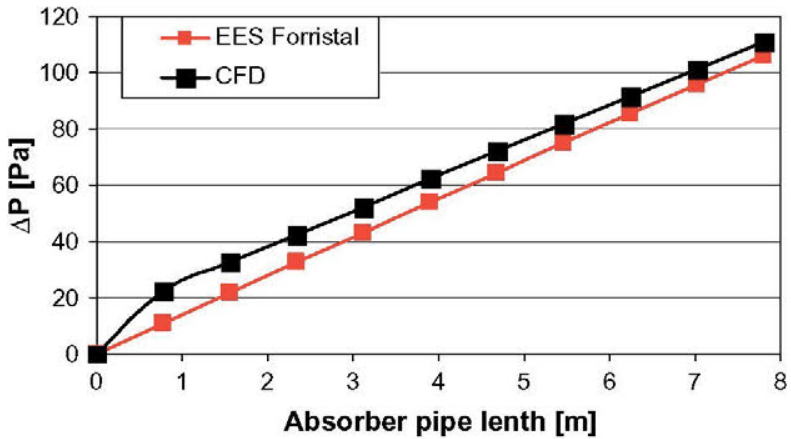

Fig. 8. Pressure drop comparison between CFD and EES model ( massflow $=47.71 /$ $\min , \mathrm{DNI}=933.7 \mathrm{~W} / \mathrm{m}^{2}$.

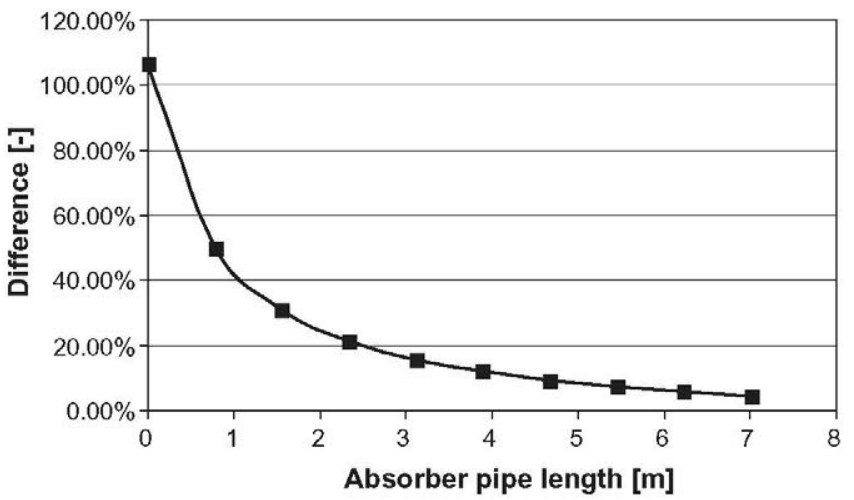

Fig. 9. Discrepancies in pressure drop evaluation between CFD and EES model $\left(\right.$ massflow $\left.=47.7 \mathrm{l} / \mathrm{min}, \mathrm{DNI}=933.7 \mathrm{~W} / \mathrm{m}^{2}\right)$.

length of the LS-2 tube tested in AZTRAK. Nevertheless, there is a clear tendency to increase the discrepancies in the temperature evaluation of the heat transfer fluid in the tube with its length due to the error propagation in the evaluation of temperatures. Both models are based in very different assumptions, as CFD makes a finite-element approximation and EES uses numerical correlations.

We have also estimate with our CFD methodology the experimental data shown in Table 1 . The results are given in Table 4. The discrepancy between the experimental data and the computational results for the whole absorbing pipe length is less than $10 \%$ in every case. This estimation error takes into consideration that some experimental uncertainties and conditions regarding wind velocity and air temperature are not fully integrated in our CFD model that establishes a common atmospheric conditions for the seven cases. In particular, our external conditions are based on LS-2 \#1 $\left(21.2^{\circ} \mathrm{C}, 2.6 \mathrm{~m} / \mathrm{s}\right.$ wind speed), giving the lowest discrepancy in comparison with available experimental data. Discrepancies with experimental data increase as the experimental conditions differ from LS-2 \#1, which was taken as reference for the thermal losses evaluation. Nevertheless, we consider that this set of calculations serves for the qualification purpose of our model to be used in a comparison between the performance of a plain internal tube and a finned internal tube.

Table 4

Comparison between CFD and LS-2 collector experimental data.

\begin{tabular}{lllllll}
\hline & $\begin{array}{l}T \text { in data } \\
\left({ }^{\circ} \mathrm{C}\right)\end{array}$ & $\begin{array}{l}T \text { out data } \\
\left({ }^{\circ} \mathrm{C}\right)\end{array}$ & $\begin{array}{l}\Delta T \text { data } \\
\left({ }^{\circ} \mathrm{C}\right)\end{array}$ & $\begin{array}{l}T \text { out } \\
\mathrm{CFD}\left({ }^{\circ} \mathrm{C}\right)\end{array}$ & $\begin{array}{l}\Delta T \text { CFD } \\
\left({ }^{\circ} \mathrm{C}\right)\end{array}$ & $\begin{array}{l}\text { Diff. } \\
\Delta T(\%)\end{array}$ \\
\hline LS-2 \#1 & 102.2 & 124 & 21.8 & 123.51 & 21.31 & 2.25 \\
LS-2 \#2 & 151 & 173.3 & 22.3 & 172.02 & 21.02 & 5.73 \\
LS-2 \#3 & 197.5 & 219.5 & 22 & 218.29 & 20.79 & 5.49 \\
LS-2 \#4 & 250.7 & 269.4 & 18.7 & 267.92 & 17.22 & 7.94 \\
LS-2 \#5 & 297.8 & 316.9 & 19.1 & 315.82 & 18.02 & 5.66 \\
LS-2 \#6 & 379.5 & 398 & 18.5 & 397.41 & 17.91 & 3.21 \\
LS-2 \#7 & 355.9 & 374 & 18.1 & 373.13 & 17.23 & 4.79 \\
\hline
\end{tabular}

Table 5

Tube configurations for finned parabolic trough collectors.

\begin{tabular}{|c|c|c|c|c|c|c|}
\hline \multirow[t]{2}{*}{ Tube } & \multirow{2}{*}{$\begin{array}{l}\text { External } \\
\text { structure } \\
\text { Outer } \\
\text { diameter } \\
(\mathrm{mm})\end{array}$} & \multirow{2}{*}{$\begin{array}{l}\text { Tube } \\
\text { thickness } \\
(\mathrm{mm})\end{array}$} & \multicolumn{4}{|c|}{ Internal surface } \\
\hline & & & $\begin{array}{l}\text { Fin } \\
\text { height } \\
(\mathrm{mm})\end{array}$ & $\begin{array}{l}\text { Number } \\
\text { of starts } \\
(-)\end{array}$ & $\begin{array}{l}\text { Helix } \\
\text { angle } \\
\text { (deg) }\end{array}$ & $\begin{array}{l}\text { Internal } \\
\text { nominal } \\
\text { diameter } \\
(\mathrm{mm})\end{array}$ \\
\hline \#1 & 70 & 2 & 2 & 10 & 25 & 66 \\
\hline \#2 & 70 & 2 & 2 & 5 & 25 & 66 \\
\hline \#3 & 70 & 2 & 2 & 10 & 16 & 66 \\
\hline$\# 4$ & 70 & 2 & 2 & 5 & 16 & 66 \\
\hline
\end{tabular}

Table 6

Main parameters of CFD simulation regarding models for finned tubes.

\begin{tabular}{llllll}
\hline Case & $\begin{array}{l}\text { Number } \\
\text { of Nodes }\end{array}$ & $\begin{array}{l}\text { Partition } \\
\text { length }\end{array}$ & $\begin{array}{l}\text { Required } \\
\text { partitions }\end{array}$ & $\begin{array}{l}\text { Simulation } \\
\text { total } \\
\text { length }(\mathrm{m})\end{array}$ & Comments \\
\hline Tube \#1 & $\sim 1.109 .000$ & 0.48719 & 16 & 7.795 & One helix turn \\
Tube \#2 & $\sim 1.079 .000$ & 0.48719 & 16 & 7.795 & One helix turn \\
Tube \#3 & $\sim 1.315 .000$ & 0.779564 & 10 & 7.795 & One helix turn \\
Tube \#4 & $\sim 1.280 .000$ & 0.779564 & 10 & 7.795 & One helix turn \\
\hline
\end{tabular}

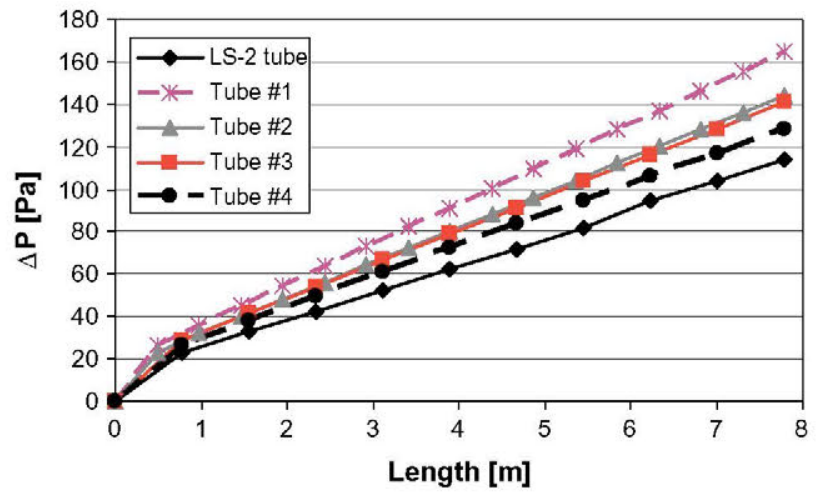

Fig. 10. Pressure drop across the absorbing tube of each finned configuration and the reference case (LS-2 \#1), vacuum tube, massflow $=47.7 \mathrm{l} / \mathrm{min} \mathrm{DNl}=933.7 \mathrm{~W} /$ $\mathrm{m}^{2}$. 
Regarding pressure losses evaluation, there is a difference of about $5 \%$ between the estimation of EES and our CFD model. The reason is that EES basically solves the empirical correlation for

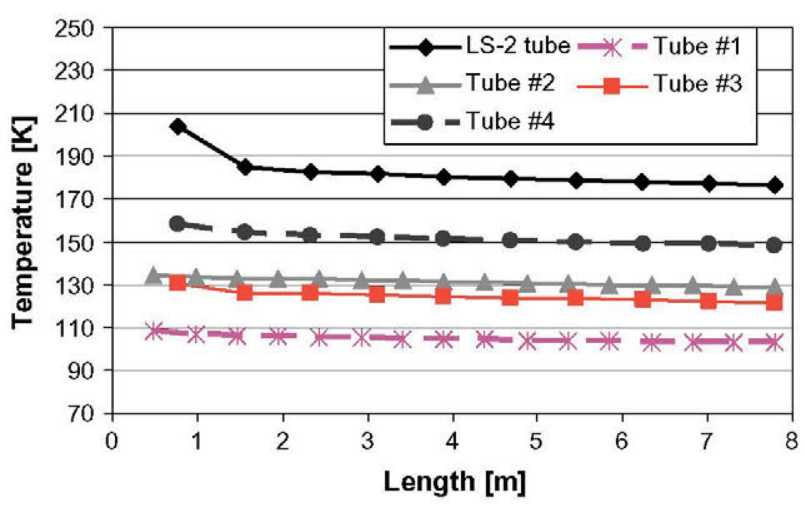

Fig. 11. Temperature difference profile between maximum external and minimum internal surface across the absorbing tube of each finned configuration and the reference case (LS-2 \#1), vacuum tube, massflow $=47.71 / \mathrm{min}, \mathrm{DNI}=933.7 \mathrm{~W} / \mathrm{m}^{2}$.

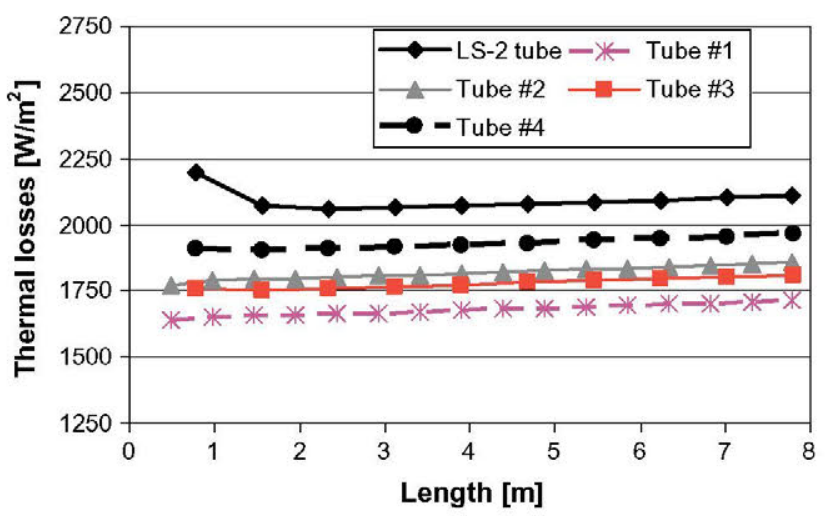

Fig. 12. Mean surface thermal losses across the absorbing tube of each finned configuration and the reference case for an outlet heat transfer temperature of $124^{\circ} \mathrm{C}$, vacuum tube, massflow $=47.7 \mathrm{l} / \mathrm{min}$ and $\mathrm{DNI}=933.7 \mathrm{~W} / \mathrm{m}^{2}$. the long tube applied to the whole pipe analysis, as in opposition to our CFD model that takes into account the turbulence development at the entrance to the pipe. Fig. 9 shows how this effect becomes less important as the tube length increases. In any case, both models have uncertainties about the estimation of the turbulence at the massflow inlet as it will depend on the connecting equipment configuration. On the other hand, Forristal [16] and Moss and Brosseau [19] reported that pressure drop measurements have uncertainties in the range $2-5 \%$, comparable to our numerical discrepancies.

\section{Analysis of finned parabolic trough tubes}

We have evaluated the technical advantages and disadvantages of the application of internal finned tubes as receiver structure of parabolic trough collectors. For that purpose we have analysed operational key aspects as the temperature difference between external and internal tube surfaces, what is related to exergy losses of the thermal energy transfer from the solar radiation to the heat transfer fluid; the pressure losses, involved in the parasitic losses of the plant; and the temperature gradients in the tube that affects its structural integrity.

We have studied four fin configurations that are summarised in Table 5 . We have analysed $70 \mathrm{~mm}$ outer diameter tubes, as it is the case of most available tubes for commercial parabolic trough solar plants as EUROTROUGH or LS-3 (through collector from the company Luz Systems, similar to LS-2), with $2 \mathrm{~mm}$ thickness and $2 \mathrm{~mm}$ height fins. The four configurations differ in the helix angle and the amount of pins at the internal cross section. In particular, the helix angle determines the partition length in our tube model, as we have fixed our simulation domain to one helix turn for cell compatibility and simplicity in the numerical coupling between each simulated section. Table 6 shows the main parameters in our simulation methodology for each configuration, what differ basically in the amount of tube partitions. The total length of the tube is $7795 \mathrm{~m}$, as it was the case of the AZTRAK facility for a better comparison with the plain tube model previously described.

The pressure analysis for the finned tubes and the comparison at each tube section is shown in Fig. 10, with an increase in the
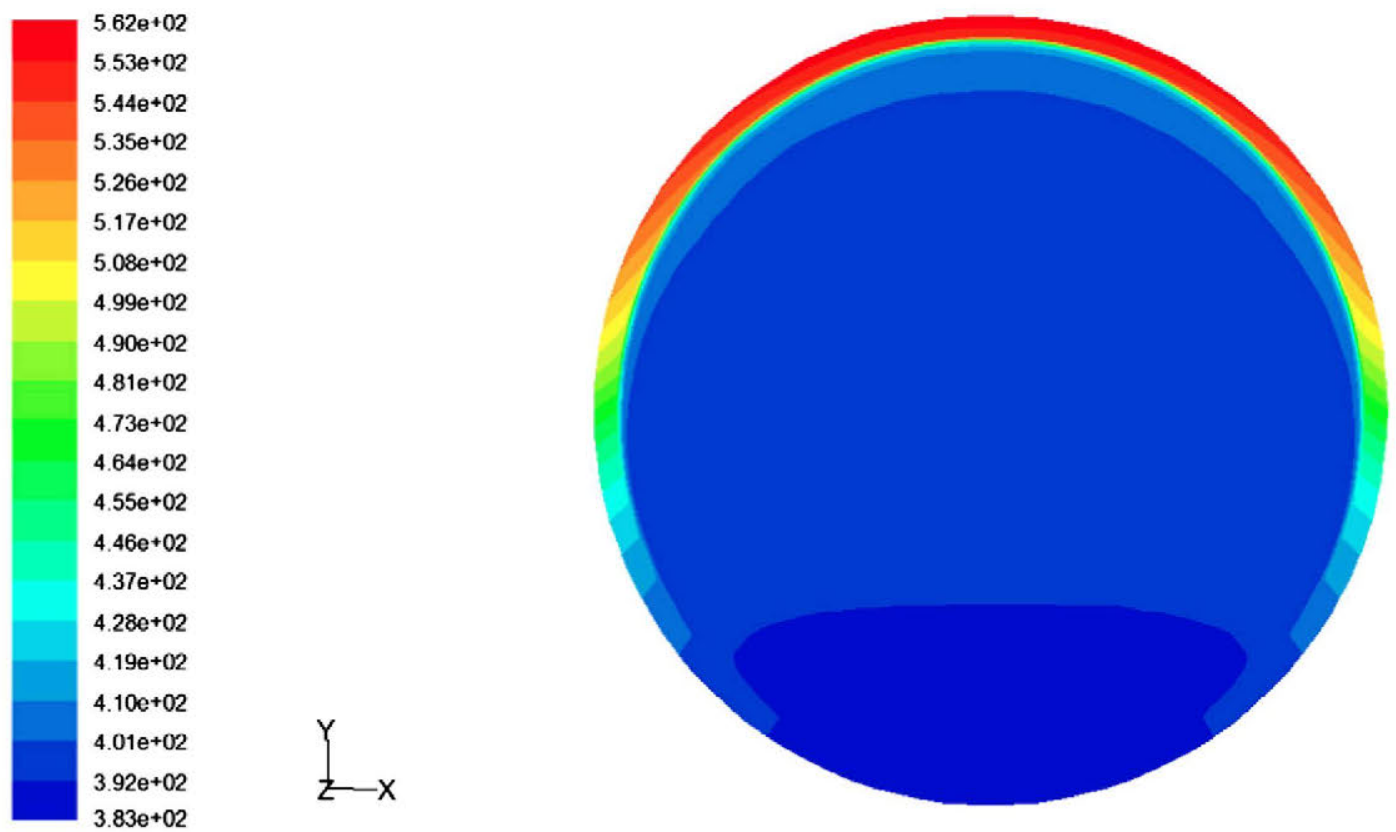

Fig. 13. Estimated contours of temperature in the outlet of the $\mathrm{LS}-2$ tube (massflow $=47.71 / \mathrm{min}, \mathrm{DNI}=933.7 \mathrm{~W} / \mathrm{m}^{2}$ ). 
pressure drop between a $10 \%$ and $50 \%$ depending of the tube design (helix angle and number of pins). This is the main drawback of the finned design, as the pressure drop increase in the practical application into a concentrated solar plant can imply a penalty to the global efficiency of the plant due to the increase in the pumping power and, hence, the parasitic losses.

The thermal comparison between the four finned analysed tubes and the reference case corresponding to the LS-2 tube section tested in AZTRAK is shown in Fig. 11, where the temperature difference between internal and external tube surface is plotted. There is up to a $40 \%$ reduction in a finned tube design, what implies a potential, either to operate at higher temperatures in the heat transfer fluid outlet, or keep the outlet temperature with a reduc- tion of the thermal losses as a consequence of the reduction of the external surface temperature in the tube.

We have applied the previous relation for the thermal losses that was obtained for the operational conditions (temperatures, massflow, etc.) in which our comparison is made and the result is provided in Fig. 12. A reduction in thermal losses up to $18 \%$ is reached for the same heat transfer fluid temperature outlet of $124^{\circ} \mathrm{C}$. At that temperature, the collector has a thermal efficiency of 0.725 as reported and taking into account its optical efficiency of 0.731 [18], our estimated reduction of the thermal losses will lead to an efficiency of 0.726 , what means an increase in the performance of the collector of the order of $0.1 \%$. Nevertheless, if the collector operates close to the conditions of a commercial
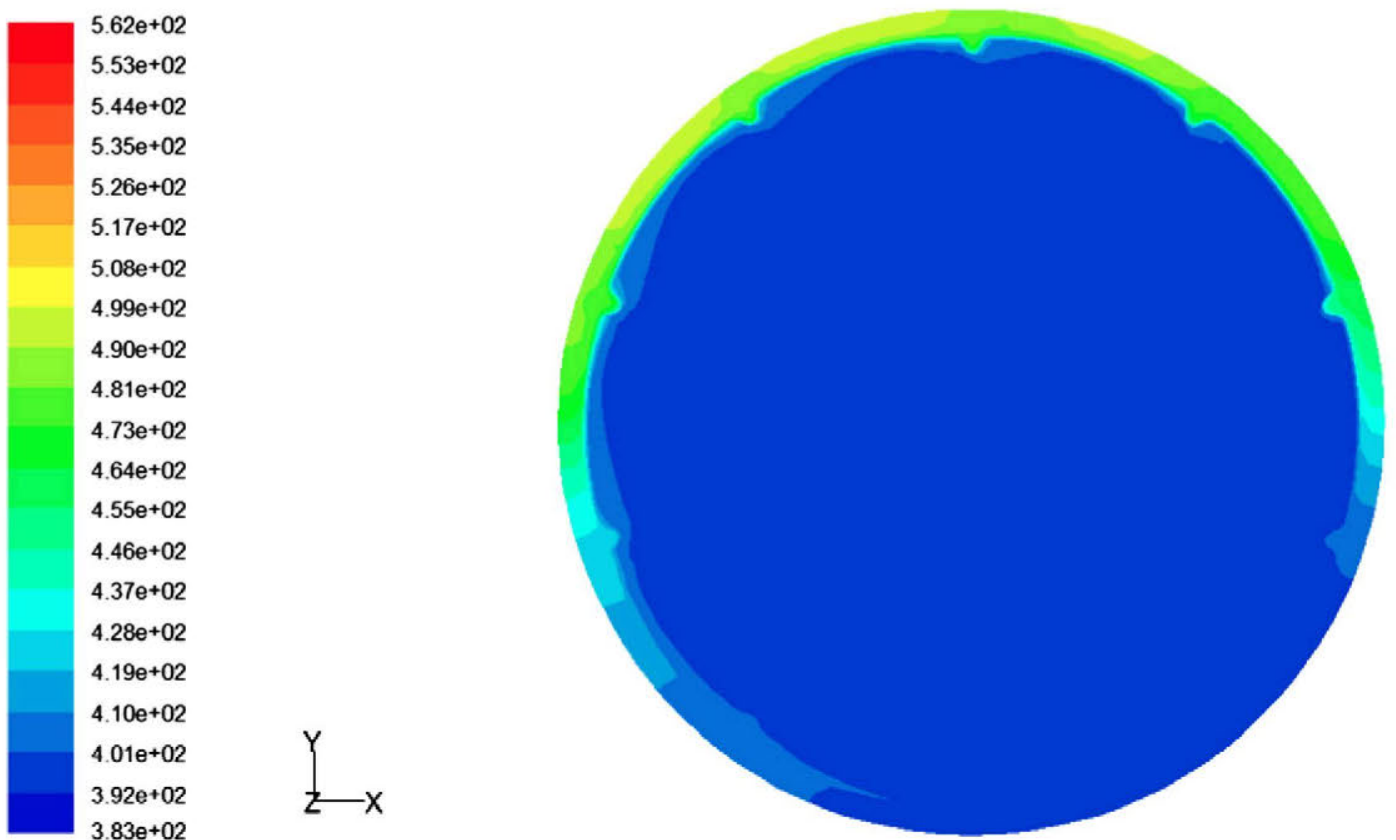

Fig. 14. Estimated contours of temperature in the outlet of tube \#1 (massflow $\left.=47.71 / \mathrm{min}, \mathrm{DNI}=933.7 \mathrm{~W} / \mathrm{m}^{2}\right)$.
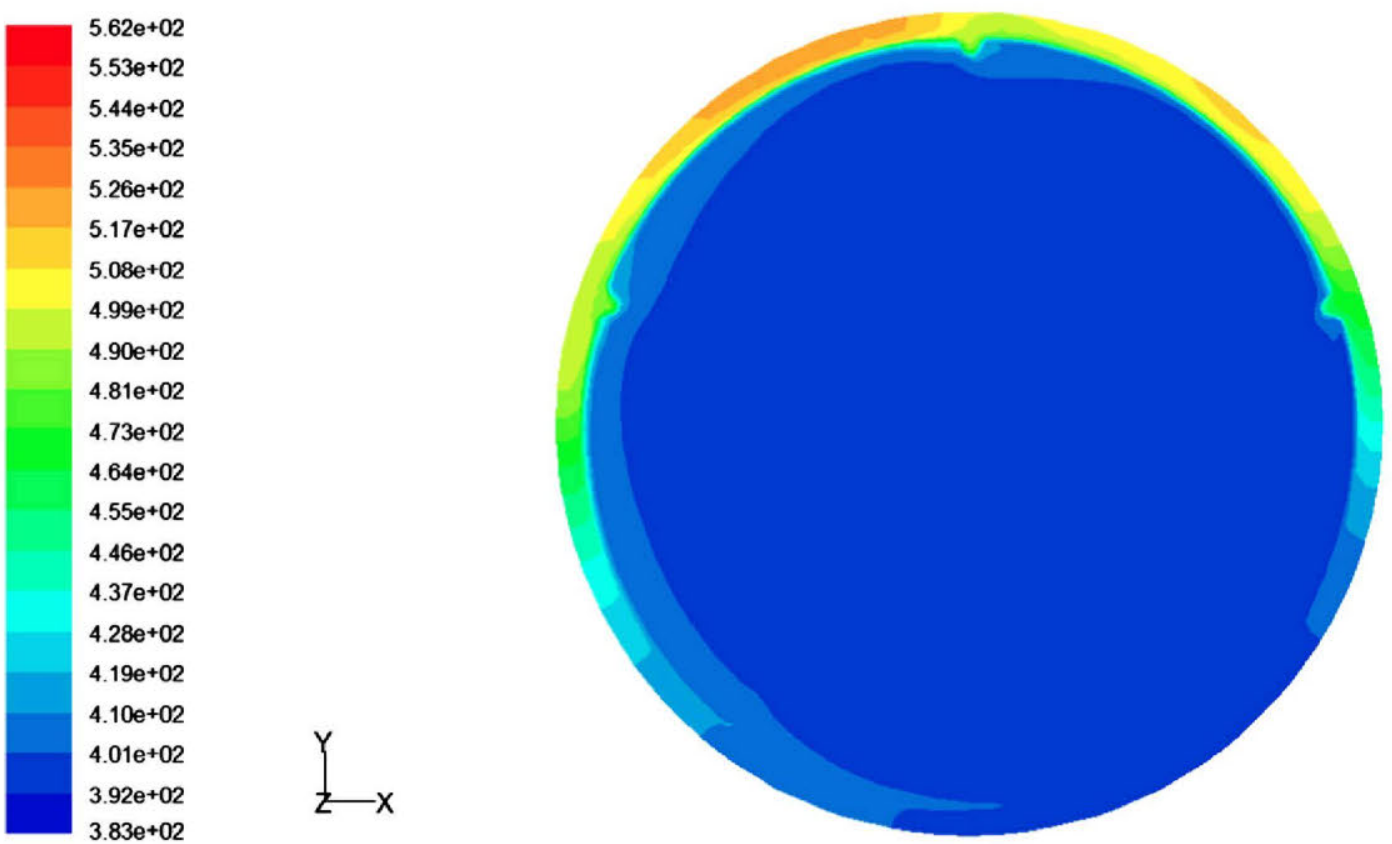

Fig. 15. Estimated contours of temperature in the outlet of tube \#2 (massflow $\left.=47.71 / \mathrm{min}, \mathrm{DNI}=933.7 \mathrm{~W} / \mathrm{m}^{2}\right)$. 
thermal solar plant and tested in case LS-2 \#6 (Table 1), the reported thermal efficiency is 0.6234 , and our estimation of the new performance, with a $18 \%$ reduction in thermal losses, is 0.642 , what means a $3 \%$ of thermal production enhancement and electricity production.

In our thermal analysis, CFD gives a detailed estimated description of the temperature distribution in the absorbing tube. Figs. 13-17 shows the contours of temperature obtained by our CFD model at the outlet each analysed tube, corresponding to the hottest part of each tube. The radiation absorbing size of the tube is easily identified by the red coloured section, where the highest temperature is reached. The fin structure can be easily identified as well. The most important issue regarding the comparison between the contours of temperature in the tube is the reduction in the temperature gradients in the tube material, what implies less mechanical stress and a lower tube bending during stable operation and transients, what makes the tube itself more reliable in the long term.

We have also evaluated the effect of the un-homogeneity of the thermal flux absorbed in the tube as consequence of the concentration optics. Fig. 18 shows the same case as in Fig. 14 but for a homogeneous energy deposition in the tube. Temperature profiles are significantly different, symmetric in the case of a homogeneous heat deposition and leading to peak temperatures $90^{\circ} \mathrm{C}$ lower. Therefore, the 3-D analysis seems to be compulsory for a correct evaluation of thermal-induced effects in the tubes.

A brief summary of the evaluation of the performance of a plain internal tube applied to solar thermal parabolic trough collector for
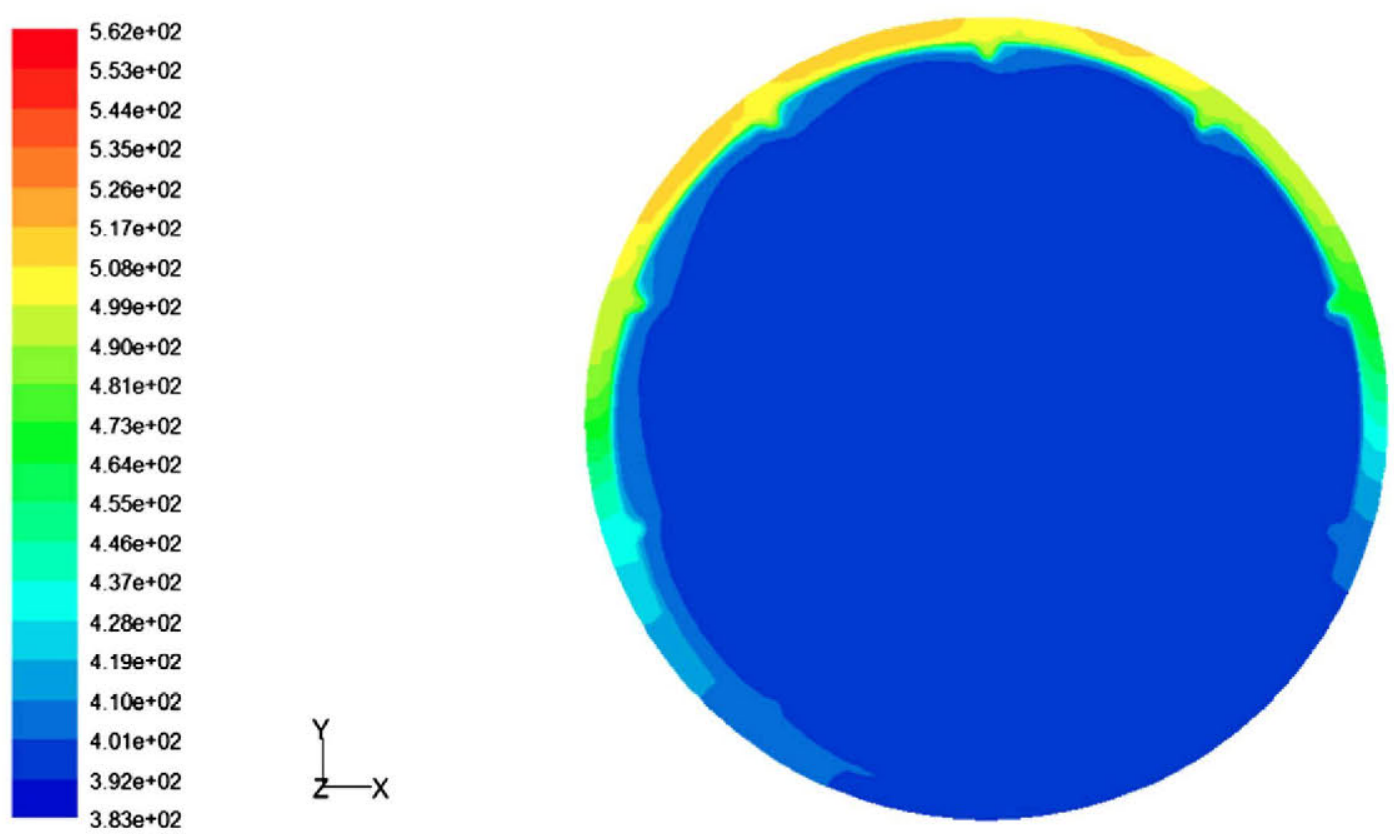

Fig. 16. Estimated contours of temperature in the outlet of tube \#3 (massflow $=47.7 \mathrm{l} / \mathrm{min}, \mathrm{DNl}=933.7 \mathrm{~W} / \mathrm{m}^{2}$ ).
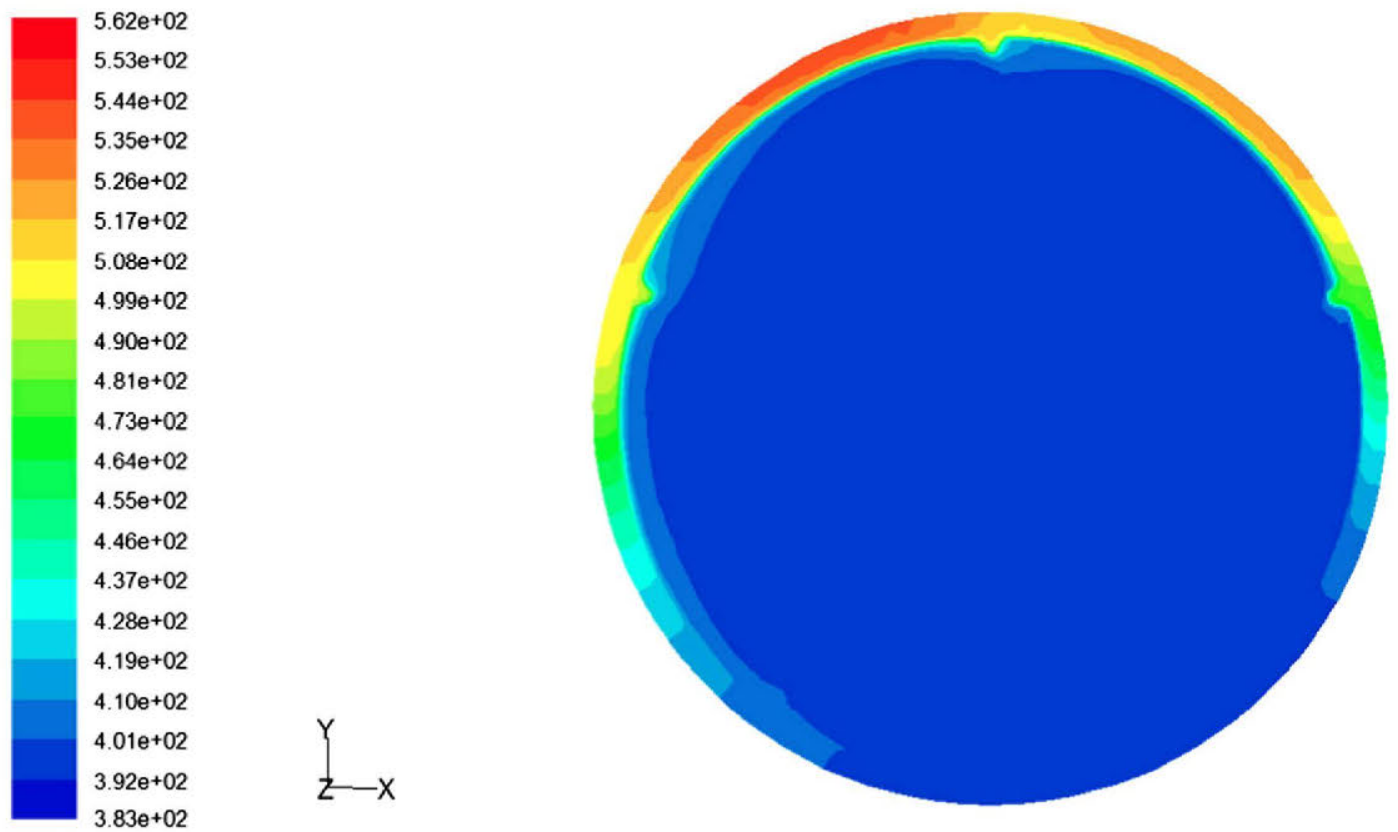

Fig. 17. Estimated contours of temperature in the outlet of tube \#4 (massflow $=47.7 \mathrm{l} / \mathrm{min}, \mathrm{DNI}=933.7 \mathrm{~W} / \mathrm{m}^{2}$ ). 


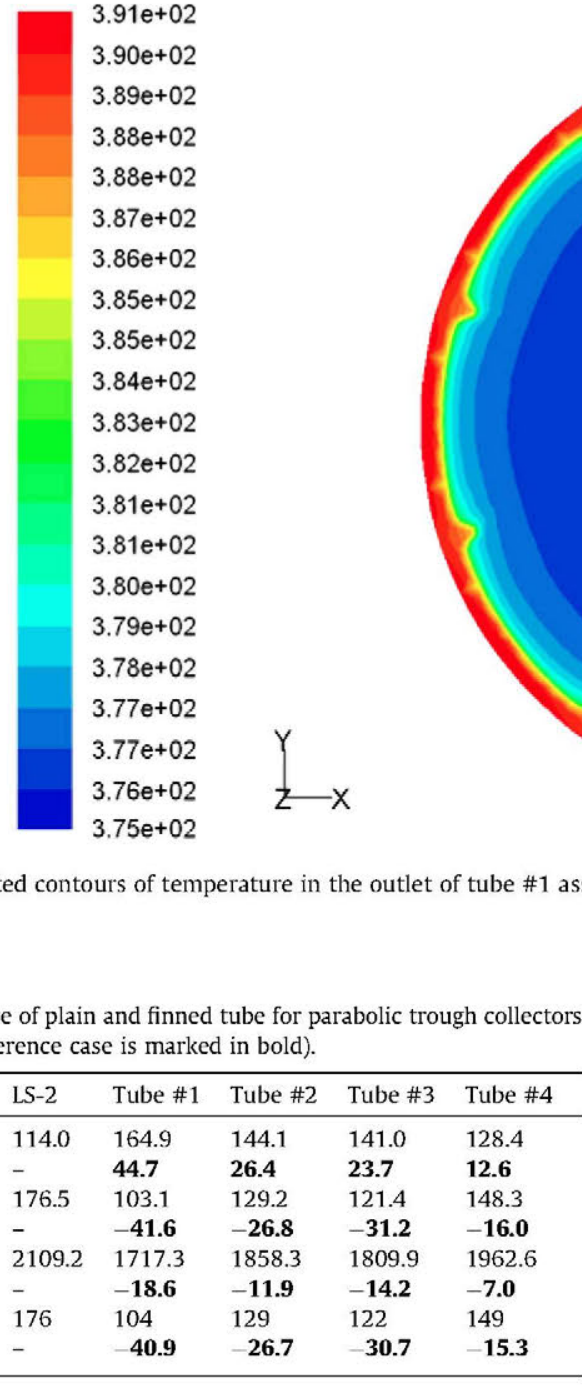

Table 7

Summary of the performance of plain and finned tube for parabolic trough collectors (the difference with LS2 reference case is marked in bold).

\begin{tabular}{llllll}
\hline & LS-2 & Tube \#1 & Tube \#2 & Tube \#3 & Tube \#4 \\
\hline Pressure losses (Pa) & 114.0 & 164.9 & 144.1 & 141.0 & 128.4 \\
Diff. with LS2 $(\%)$ & - & $\mathbf{4 4 . 7}$ & $\mathbf{2 6 . 4}$ & $\mathbf{2 3 . 7}$ & $\mathbf{1 2 . 6}$ \\
$\Delta T$ surfaces $\left({ }^{\circ} \mathrm{C}\right)$ & 176.5 & 103.1 & 129.2 & 121.4 & 148.3 \\
Diff. with LS2 $(\%)$ & - & $-\mathbf{4 1 . 6}$ & $-\mathbf{2 6 . 8}$ & $-\mathbf{3 1 . 2}$ & $-\mathbf{1 6 . 0}$ \\
Thermal losses $\left(\mathrm{W} / \mathrm{m}^{2}\right)$ & 2109.2 & 1717.3 & 1858.3 & 1809.9 & 1962.6 \\
Diff. with LS2 $(\%)$ & - & $\mathbf{- 1 8 . 6}$ & $\mathbf{- 1 1 . 9}$ & $\mathbf{- 1 4 . 2}$ & $\mathbf{- 7 . 0}$ \\
$\Delta T$ tube $\left({ }^{\circ} \mathrm{C}\right)$ & 176 & 104 & 129 & 122 & 149 \\
Diff. with LS2 $(\%)$ & - & $\mathbf{4 0 . 9}$ & $\mathbf{2 6 . 7}$ & $\mathbf{- 3 0 . 7}$ & $\mathbf{- 1 5 . 3}$ \\
\hline
\end{tabular}

electricity production, as the case of the LS-2, compared with a proposed set of internal finned tubes with Syltherm 800 as heat transfer fluid is shown in Table 7, where:

- $\Delta T$ surface is the difference between the maximum external and internal surface, and

- $\Delta T$ tube is the difference between the maximum external surface temperature and the heat transfer fluid, what included the fluid boundary layer.

The red coloured cells highlight the quantification of the drawback effect of the utilisation of internal finned tube corresponding to the increase of the pressure losses in the tube. The improvements in the performance of the tube are remarked in blue with the relative improvement of the temperature differences and thermal losses. Every relative figure has as reference the LS-2 value.

\section{Conclusion}

This paper has analysed the effect of the utilization of internal finned tubes for the design of parabolic trough collectors with computational fluid dynamics tools. Our numerical approach has been qualified with the estimation of experimental data in which the phenomena involves in finned tube analysis and solar irradiation of parabolic trough collector. The application of finned tubes to the design of parabolic trough collectors must take into account features as the pressure losses, thermal losses and thermomechanical stress and thermal fatigue. We have proposed a set of finned tube configurations that has been compared with a reference commercial tube. Our analysis shows how the parasitic losses associated to the pressure losses in the tube will increase with the number of fins and its helix angle. On the other hand, thermal losses and temperature gradients are reduced producing an increase in the thermal and exergetic efficiency of the collector. In previous work, for a $20 \mathrm{MWe}$ solar plant cooled by oil $[27,28]$, assuming an inlet/outlet field temperatures of $250 / 393.7^{\circ} \mathrm{C}$ and a massflow of $171.6 \mathrm{~kg} / \mathrm{s}$ at an inlet pressure of $32 \mathrm{bar}$, the parasitic losses were evaluated in $2.6 \%$ (536 kWe). With this value and according to our analysis are obtained a $40 \%$ increase of parasitic losses (hence $750 \mathrm{kWe}$ ) with a $3 \%$ improvement of the collector efficiency (thus producing $20.6 \mathrm{MWe}$ ). This result will lead to a plant performance enhancement of $2 \%$, with an expected reduction of operation and maintenance cost due to the reduction of the tube replacement rate. Reduction motivated by the decrease in tubes mechanical fatigue that would compensate the cost increase of the finned collector tube that should be determined in detail. We are optimistic about the collector cost increase as the steel addition is less than $2 \%$ and its cost is much lower than the absorbing coating, the glass and the glass-tube vacuum system. The fabrication cost will be increased for a finned tube. Adding the extra manufacturing cost, we foresee a receptor cost increase of the order of $5 \%$, what, in terms of the solar field, it means a $1 \%$, what finally lead to a roughly $0.5 \%$ increase of the cost of the plant. The plant efficiency is expected to be enhanced a $2 \%$, what justify their application in a preliminary cost analysis. Nevertheless, the effect of the plant size and power should be evaluated in detail, but we believe that an optimization of such design integrated into a thermal concentrated solar plant can be an open research activity for the future.

\section{References}

[1] UNFCCC, 1997. Kyoto protocol to the United Nations framework convention on climate change. FCCC/CP/1997/7/Add.1. <http://www.unfccc.de>

[2] Frier SD, Cohen GE, Cable RG. An overview of the Kramer Junction parabolic trough solar electric system. In: Proceedings of ANZSES 36 th annual conference, Christchurch, New Zealand, 1998, p. 547-54. 
[3] Farooq M, Raja IA. Optimisation of metal sputtered and electroplated substrates for solar selective coatings. Renewe Energy 2008;33:1275-85.

[4] Eck M, Zarza E, Eickhoff M, Rheinländer J, Valenzuela L. Applied research concerning the direct steam generation in parabolic troughs. Sol Energy 2003;74:341-51.

[5] Moens L, Blake D. Mechanism of hydrogen formation in solar parabolic trough receivers. Technical Report NREL/TP-510-42468, NREL; February 2008.

[6] Lei $\mathrm{D}$, Wang $\mathrm{Z}$, Li J. The calculation and analysis of glass-to-metal sealing stress in solar absorber tube. Renew Energy 2010;35:405-11.

[7] Unidad de Formación en Energía y Medioambiente 2006. Curso sobre sistemas solares de concentración. CIEMAT, 2-11 de octubre de 2006, Madrid, España.

[8] Pfänder M, Lüpfert E, Pistor P. Infrared temperature measurements on solar trough absorber tubes. Sol Energy 2007;81:629-35.

[9] ANSYS Inc., 2008. CFD flow modeling software \& solutions from FLUENT. http://www.fluent.com/.

[10] Ravi Kumar K, Reddy KS. Thermal analysis of solar parabolic trough with porous disc receiver. Appl Energy 2009;86:1804-12.

[11] Browne MW, Bansal PK. An overview of condensation heat transfer on horizontal tube bundles. Appl Therm Eng 1999;19:565-94

[12] Cui W, Li L, Xin M, Jen T, Chen Q, Liao Q. A heat transfer correlation of flow boiling in micro-finned helically coiled tube. Int J Heat Mass Transfer 2006:49: 2851-8.

[13] Li L, Cui W, Liao Q, Mingdao X, Jen T, Chen Q. Heat transfer augmentation in 3D internally finned and microfinned helical tube. Int J Heat Mass Transfer 2005; 48:1916-25.

[14] Zheng B, Lin CX, Ebadian MA. Combined laminar forced convection and thermal radiation in a helical pipe. Int $J$ Heat Mass Transfer 2000;43: 1067-78.

[15] Zdaniuk GJ, Chamra LM, Mago PJ. Experimental determination of heat transfer and friction in helically-finned tubes. Exp Therm Fluid Sci 2008:32:761-75.

[16] Forristal R. Heat transfer analysis and modeling of a parabolic trough solar receiver implemented in engineering equation solver. NREL Technical Report, Golden, Colorado, USA; 2003.
[17] F-Chart Software. EES (engineering equation solver); 2005.<http://www. fchart.com>.

[18] Dudley VE, Kolb GJ, Mahoney AR, Mancini TR, Matthews CW. Test results: SEGS LS-2 solar collector. SAND94-1884. Albuquerque (NM): SANDIA National Laboratories; 1994.

[19] Moss T, Brosseau D. Testing capabilities NSTTF (AZTRAK) rotating platform. Albuquerque (New Mexico, USA): Sandia National Laboratories; 2007.

[20] Wu YL, Ng EYK, Wong K. Numerical study of the swirl flow in F-5E intake with subsonic speeds. Math Comput Model 2008;48:447-67.

[21] Yakhot V, Orszag SA. Renormalization group and local order in strong turbulence. Nucl Phys B - Proc Suppl 1987;2:417-40.

[22] Chow TT. A review on photovoltaic/thermal hybrid solar technology. Appl Energy 2010;87:365-79.

[23] Flueckiger S, Yang Z, Garimella SV. An integrated thermal and mechanical investigation of molten-salt thermocline energy storage. Appl Energy 2011;88:2098-105.

[24] Ozceyhan V, Gunes S, Buyukalaca O, Altuntop N. Heat transfer enhancement in a tube using circular cross sectional rings separated from wall. Appl Energy 2008;85:988-1001.

[25] Lemouedda A, Schmid A, Franz E, Breuer M, Delgado A. Numerical investigations for the optimization of serrated finned-tube heat exchangers. Appl Therm Eng 2011;31:1393-401.

[26] Shabanian SR, Rahimi M, Shahhosseini M, Alsairafi AA. CFD and experimental studies on heat transfer enhancement in an air cooler equipped with different tube inserts. Int Commun Heat Mass Transfer 2011;38:383-90.

[27] Montes MJ, Abánades A, Martínez-Val JM. Thermodynamic model analysis of parabolic trough collectors using oil, water/steam or molten salt as heat transfer fluid. In: 14th Biennial CSP SolarPaces symposium. Las Vegas, Nevada, USA; 4-7 March, 2008.

[28] Montes MJ, Abánades A, Martínez-Val JM. Thermofluidynamic model and comparative analysis of parabolic trough collectors using oil, water/steam, or molten salt as heat transfer fluid. J Sol Energy Eng 2010;132. 